\title{
Pericardial Synovial Sarcoma: A Case Report and Review of Literature
}

\author{
Dela Pinta $C^{1 *}$, Hernanz $\mathrm{R}^{1}$, Montero $\mathrm{A}^{2}$, Muñoz $\mathrm{T}^{1}$, Polo $\mathrm{A}^{1}$ and Sancho $\mathrm{S}^{1}$ \\ ${ }^{1}$ Department of Radiation Oncology, Ramón y Cajal Hospital, Spain \\ ${ }^{2}$ Department of Radiation Oncology, Grupo HM Madrid, Spain
}

Submission: August 08, 2018; Published: September 28, 2018

*Corresponding author: Dela Pinta C, Department of Radiation Oncology, Ramón y Cajal Hospital, Spain, Email: cdelapinta88@gmail.com

\begin{abstract}
Pericardial Synovial Sarcoma (PSS) is a rare malignant soft-tissue tumor. Early diagnosis and multimodal management could be improving patient outcome. PSS diagnose is difficult due to localization but an aggressive disease. Using all the available medical methods is important to avoid progression and recurrence of this kind of tumors. Multidisciplinary treatment is necessary, and radiotherapy is a good and safe option. We present our experience of a forty-year-old man with this tumor.
\end{abstract}

Keywords: Pericardial; Sarcoma; Treatment

Abbreviations: PSS: Pericardial Synovial Sarcoma; IORT: Intraoperative Radiation Therapy; RT: Radiotherapy; CT: Chemotherapy

\section{Introduction}

Pericardial synovial sarcoma is a type of sarcoma uncommon [1]. It is usually diagnosed in young adults. Patient's present unspecific symptoms, like fever, cough, pain chest and fatigue. In other cases, patients present pericardial effusion and cardiac tamponade. Only 30 cases of synovial sarcoma of the pericardium have been reported in the English language literature, 20 included follow-ups [2,3].

Case Report
The purpose of this report is to describe the case of a patient with pericardial synovial sarcoma whose initial presentation was severe pericardial effusion. Despite treatment, the patient died in one year. Then, we reviewed the medical literature for the epidemiology, clinical picture, and relevance of complementary imaging tests, therapeutic conduct and prognosis of this neoplasm.

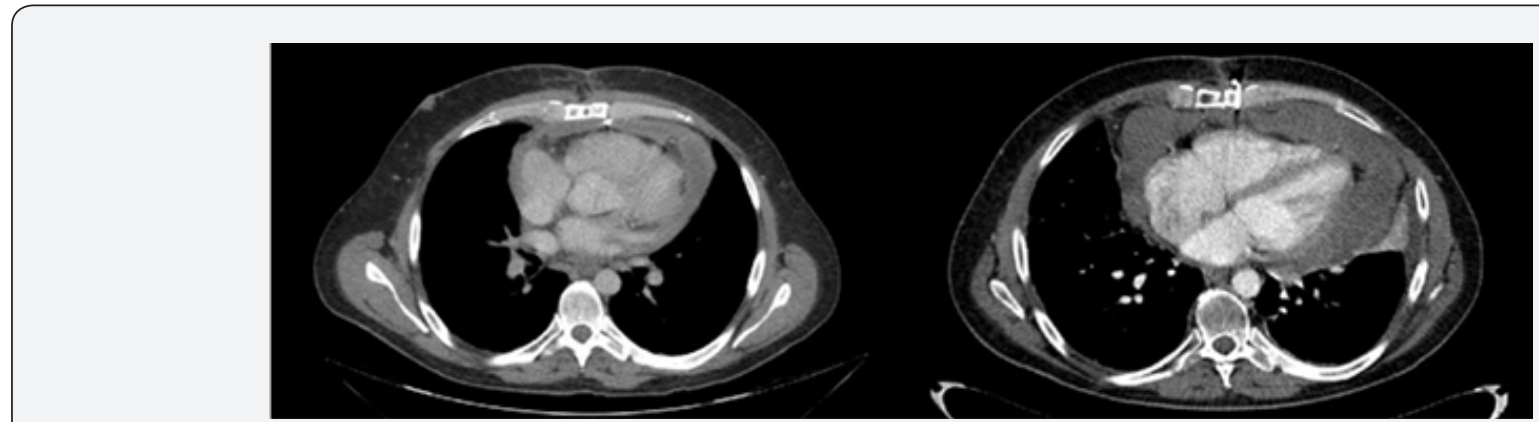

Figure 1: CT with pericardial mass.

40-year-old man visited our Hospital in June 2014 due to chest pain. The physical examination had no abnormal findings. After admission, the chest X-ray indicated cardiomegaly and echocardiography showed dates of pericardial effusion. The patient received treatment and was discharged from hospital after one week with pericarditis diagnosis. Four months later, he started with similar symptoms and echocardiography showed massive pericardial effusion with a tumorous region in the pericardial space. Echocardiography showed a big mass with compression of right cavities without stenosis, gradient valve tricuspid of $3,7 \mathrm{mmHg}$. The chest CT, as well as confirming the effusion, revealed a pericardial cystic mass with pericardial thickening (Figure 1). Is suggested of neoplasm like mesothelioma or sarcoma. Pericardiocentesis was performed and $1000 \mathrm{~mL}$ of 
pericardial fluid was drained. According to these findings, surgical resection through pericardiectomy with median sternotomy was performed on October 2014 with pathology study. The tumor was in the pericardial space, with irregular morphology, size of $14 \times 5.7 \times 6 \mathrm{~cm}$ and $1500 \mathrm{~mL}$ serohematic pericardial fluid. Histological analysis showed spindle cells-type sarcoma, necrosis and 18 mytosis. Immunohistochemical analysis showed that the tumor cells were positive for bcl-2, CD99, vimentin and the Ki-67 proliferative index was 50\%; however, staining for $\mathrm{S} 100$ proteins, $\mathrm{CD}_{34}, \mathrm{CK} \mathrm{AE}_{1} / \mathrm{AE}_{3}$, EMA, enolasa, musclespecific actin (HHF35) and desmin was negative. On the other hand, fluorescence in situ hybridization revealed a moderate prevalence $(64 \%)$ of cells with interruption of the SYT gene (18q11.2). Final diagnosis was monophasic synovial sarcoma with poorly differentiated areas with unspecified margins. Patient had a good clinical evolution but the control CT scan three months later, showed tumor persistence, $7.5 \times 11 \times 2.8 \mathrm{~cm}$ with compression in right ventricle. The tumor grew from the inner surface of the pericardium near the origin of the pulmonary artery and ascending aorta with invasion of left atrium and right coronary. The study was completed with angiography scan. The case was evaluated in multidisciplinary committee. The specialist decided re-intervention, but complete resection was not possible because of the proximity and attachment to the great vessels. In CT scan after surgery, the mass was reduced around 50\%. In multidisciplinary committee, we discussed the possibility of adjuvant radiation therapy. Finally, patient received radiation treatment with prescription dose of 45Gy, 1.8Gy daily (Figure 2). He didn't had any toxicity. After three months, patient had a new recurrence. In committee we decided not surgery, patient received chemotherapy. Finally, patient had a new recurrence and died in 12 months after diagnosis (Figure 3).

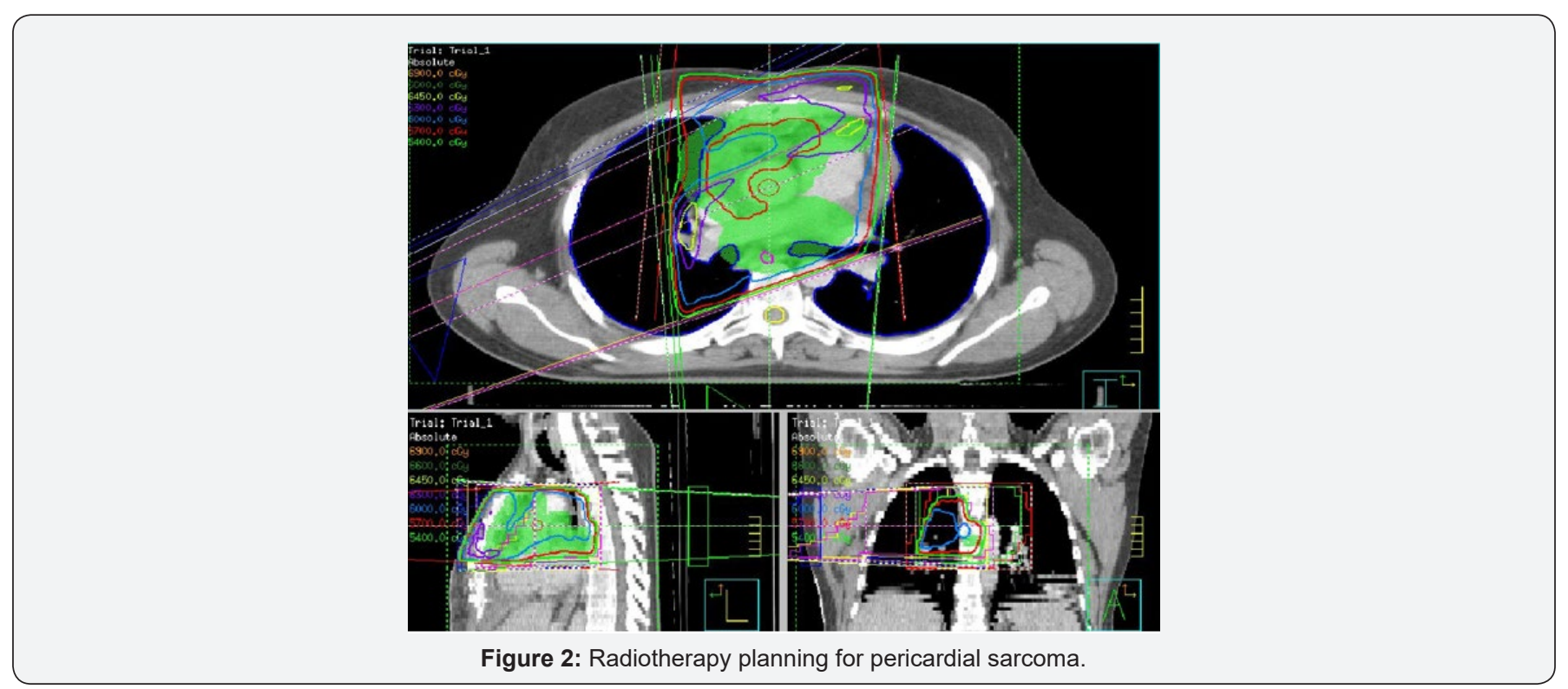

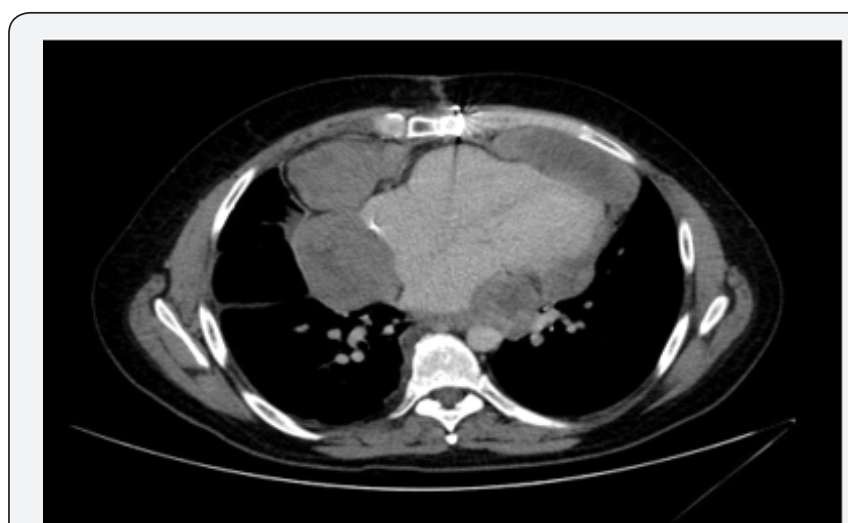

Figure 3: Tumor recurrence.

\section{Discussion}

Pericardial Synovial Sarcoma (PSS) is a rare primary malignant tumor of the heart and has an unclear prognosis. Primary cardiac tumours are uncommon, occurring less frequently than metastatic tumours with an incidence in autopsy series ranging only from $0.001-0.03 \%$ [4]. Most of the primary cardiac tumours are benign and approximately $25 \%$ of them are malignant, of which the majority are sarcomas but originating from the pericardium are exceedingly rare accounts for approximately $4.2 \%$ of primary cardiac sarcomas. In descending order of frequency, these are angiosarcoma, fibrosarcoma, rhabdomyosarcoma, and malignant fibrous histiocytoma [5]. It is more frequent in young adults between 15 and 35 years of age [6]. PSS was first described in 1978 [7]. The signs and symptoms caused by the primary cardiac sarcoma are extremely variable and nonspecific. Clinical manifestations can be divided into four categories: systemic; embolic; cardiac; and secondary to metastasis.

The most common systemic manifestations are fever, chills, fatigue, night sweats and weight loss. Embolic manifestations occur mainly in sarcomas invading the cardiac cavities, causing pulmonary or systemic embolism. Cardiac manifestations depend on the location of the tumor: predominantly pericardial, intramural or intracavitary. In the case of pericardial sarcoma, 
the most common initial clinical picture results from massive hemorrhagic pericardial effusion and cardiac tamponade [4]. The organs most often affected by primary cardiac sarcoma metastases are the lungs, brain and bones. The tumors are classified into three histologic subtypes: monophasic, biphasic and poorly differentiated [6]. The histologic type was judged to be monophasic in the current case. Biphasic PSS tumor composed of spindled and epithelioid areas or as a monophasic tumor, characterized by the spindle cell component only. Although immunological characteristics, such as positivity for bcl-2 and CD99, are not exclusive to synovial sarcoma, a definitive diagnosis can be made based on the presence of the chromosomal change $t(X ; 18)(p 11 ; q 11)$, the cytogenetic hallmark of synovial sarcoma. The SS18 gene on 18q and either the SSX1 or SSX2 gene on Xp undergo reciprocal translocation, forming a fusion gene, SS18SSX, with the subsequent production of fusion proteins; more than $90 \%$ of synovial sarcomas present with this characteristic molecular signature. In addition, biphasic synovial sarcoma has a SYT-SSX1 fusion transcript, whereas SYT-SSX2-positive tumors are monophasic synovial sarcomas [6]. It is most frequent presenting symptom is signs of cardiac tamponade; subsequent diagnostic imaging, including echocardiography or chest CT, reveals a pericardial mass requiring biopsy for diagnosis [8].

An important survival factor is complete resection, but it is rare. Radiotherapy and chemotherapy are indicated in incomplete resection o to prevent locoregional recurrence. While broad surgical resection is the first choice for treatment, chemotherapy and radiotherapy are carried out when surgical resection is unsuccessful; however, the prognosis of this disease is poor [9]. Median survival was around 15-25 months in some series.

Table 1: Cases reports with follow-up.

\begin{tabular}{|c|c|c|c|c|c|c|c|c|}
\hline Reference & Age & $\begin{array}{l}\text { Gen- } \\
\text { der }\end{array}$ & Clinical & Surgery & CT (type) & $\begin{array}{l}\text { RT (dose/ } \\
\text { Gy) }\end{array}$ & $\begin{array}{c}\text { Immunohistochemically } \\
\text { positive antigens and } \\
\text { molecular analysis }\end{array}$ & Outcome \\
\hline $\begin{array}{l}\text { Muramatsu } \\
\text { et al. [8] }\end{array}$ & 57 & M & $\begin{array}{l}\text { Cardio- } \\
\text { megaly }\end{array}$ & Incomplete & $\begin{array}{l}\text { Ifosfamide, } \\
\text { adriamycin }\end{array}$ & 50Gy & $\begin{array}{l}\text { CK, CD99 and bcl-2 Fusion } \\
\text { SYT/SSX negative. }\end{array}$ & Died at $3 y$ \\
\hline $\begin{array}{l}\text { Phatak et } \\
\text { al. [5] }\end{array}$ & 27 & M & $\begin{array}{l}\text { Dyspnea, } \\
\text { cought }\end{array}$ & Incomplete & $\begin{array}{l}\text { Ifosfamide and } \\
\text { MESNA }\end{array}$ & Yes & $\begin{array}{l}\text { BCL-2, CD 99, vimentin, } \\
\text { FLI1, enolase. EMA. SYT } \\
\text { gene: rearrangement }\end{array}$ & $\begin{array}{l}\text { Recurrence at } 9 \mathrm{~m} . \\
\text { Second line CT. } \\
\text { Stable at } 18 \mathrm{~m}\end{array}$ \\
\hline $\begin{array}{l}\text { Bezerra et } \\
\text { al. [2] }\end{array}$ & 29 & $\mathrm{~F}$ & $\begin{array}{l}\text { Dyspnea, } \\
\text { chest pain }\end{array}$ & Incomplete & 2-cycles & No & Spindle cells No analysis & $\begin{array}{c}\text { Died before second } \\
\text { cylce of CT }\end{array}$ \\
\hline \multirow[t]{4}{*}{$\begin{array}{l}\text { Cheng et al. } \\
\text { [9] }\end{array}$} & 31 & M & Fever, cought & Biopsy & No (refused) & No & $\begin{array}{l}\text { EMS, CK7, 19, AE1/AE3 } \\
\text { SYT gene: reagarrement }\end{array}$ & $\begin{array}{l}\text { Alive at the theat } \\
\text { the } 12 \mathrm{~m} \text { follow up }\end{array}$ \\
\hline & 31 & M & $\begin{array}{l}\text { Fever, night } \\
\text { sweats, chest } \\
\text { pain }\end{array}$ & Incomplete & $\begin{array}{l}\text { Doxorubicin, } \\
\text { ifosfamide, } \\
\text { diamminedic- } \\
\text { hloroplatinum }\end{array}$ & No & $\begin{array}{l}\text { CD99, calpoein, bcl-2, } \\
\text { vimentin }\end{array}$ & $\begin{array}{l}\text { Died } 27-m \text { after } \\
\text { presentation }\end{array}$ \\
\hline & & & & & & & SYT gene: reagarrement & \\
\hline & 38 & M & $\begin{array}{c}\text { Chest } \\
\text { distress, } \\
\text { shotness of } \\
\text { breath }\end{array}$ & Biopsy & & & $\begin{array}{l}\text { Vimentin, bcl-2, calponin, } \\
\text { CD99. SYT gene: } \\
\text { reagarrement }\end{array}$ & $\begin{array}{l}\text { Awaiting heart } \\
\text { transplantation }\end{array}$ \\
\hline \multirow[t]{2}{*}{$\begin{array}{l}\text { Akerström } \\
\text { et al. [12] }\end{array}$} & 54 & $\mathrm{~F}$ & $\begin{array}{l}\text { Malaise, } \\
\text { fever, chest } \\
\text { pain }\end{array}$ & Incomplete & Ifosphamide & No & $\begin{array}{l}\text { EMA, vimentin, VER EP4, } \\
\text { bcl2, CK AE1/AE3 }\end{array}$ & Died after 26-m \\
\hline & & & & & & & SYT-SSX fusion gene & \\
\hline $\begin{array}{l}\text { Moorjani et } \\
\text { al. [13] }\end{array}$ & 61 & M & Dysnea & Yes & Yes & No & EMA, CK AE3 & $\begin{array}{l}\text { Alive after } 2-m \text { of } \\
\text { surgery }\end{array}$ \\
\hline $\begin{array}{l}\text { Katakura et } \\
\text { al. [14] }\end{array}$ & 70 & $\mathrm{~F}$ & $\begin{array}{l}\text { Cought, } \\
\text { dysnea }\end{array}$ & Complete & No & No & SYT-SSX fusion gene & $\begin{array}{l}\text { Died } 79-d \text { after } \\
\text { operation }\end{array}$ \\
\hline $\begin{array}{c}\text { Korula et al. } \\
\text { [15] }\end{array}$ & 49 & M & $\begin{array}{l}\text { Dyspnea, } \\
\text { chest pain }\end{array}$ & Biopsy & Yes & No & EMA, CK(AE1/AE3), bcl2 & Palliative care \\
\hline $\begin{array}{l}\text { Zhang et al. } \\
\qquad[16]\end{array}$ & 29 & M & malaise & Incomplete & Yes & No & - & Alive at $13-\mathrm{m}$ \\
\hline $\begin{array}{l}\text { De Zwaan et } \\
\text { al. [17] }\end{array}$ & 19 & M & Dyspnea & Biopsy & - & - & $\begin{array}{c}\text { EMA, CD34, CD99, } \\
\text { vimentin and MNF116. } \\
\text { FISH }(\mathrm{X} ; 18) \text { translocation }\end{array}$ & Palliative care \\
\hline $\begin{array}{l}\text { Hing et al. } \\
\text { [18] }\end{array}$ & 15 & M & $\begin{array}{l}\text { Cought, tight } \\
\text { chest }\end{array}$ & Incomplete & $\begin{array}{c}\text { Cisplatin, } \\
\text { doxorubicin, } \\
\text { cyclophosphamide }\end{array}$ & No & EMA, vimentin, bcl2 & $\begin{array}{l}\text { Died } 31-m \text { after } \\
\text { presentation }\end{array}$ \\
\hline
\end{tabular}


Journal of Tumor Medicine \& Prevention

\begin{tabular}{|c|c|c|c|c|c|c|c|c|}
\hline & & & & & & & SYT-SSX fusion gene & \\
\hline \multirow[t]{2}{*}{$\begin{array}{l}\text { Van der } \\
\text { Mieren et } \\
\text { al. [19] }\end{array}$} & 26 & M & $\begin{array}{l}\text { Cardiac } \\
\text { tamponade }\end{array}$ & Yes & $\begin{array}{l}\text { Doxorubicin, } \\
\text { chydrochloride }\end{array}$ & Yes & EMA, vimentin, CK & Alive $>5$ years \\
\hline & & & & & & & SYT-SSX transcript & \\
\hline \multirow[t]{2}{*}{$\begin{array}{l}\text { Yano et al. } \\
\text { [20] }\end{array}$} & 22 & $\mathrm{~F}$ & $\begin{array}{l}\text { Shortness } \\
\text { of breath, } \\
\text { cought }\end{array}$ & Yes & Yes & Yes & EMA, vimentin & $\begin{array}{c}\text { No recurrence at } \\
12-\mathrm{m}\end{array}$ \\
\hline & & & & & & & SYT-SSX2 expression & \\
\hline $\begin{array}{c}\text { Anand et al. } \\
{[21]}\end{array}$ & 29 & M & $\begin{array}{l}\text { Acute } \\
\text { breathl- } \\
\text { essness }\end{array}$ & Incomplete & Yes & Yes & EMA, CD99 & Alive at $13-\mathrm{m}$ \\
\hline $\begin{array}{l}\text { Val-Bernal } \\
\text { et al. [22] }\end{array}$ & 76 & $\mathrm{~F}$ & $\begin{array}{l}\text { Unspecific } \\
\text { symptoms }\end{array}$ & Autopsy & No & No & $\begin{array}{l}\text { EMA, cytokeratin } 5,6,7, \\
\text { thrombomodulin }\end{array}$ & Died \\
\hline $\begin{array}{l}\text { Dos Santos } \\
\text { et al. [23] }\end{array}$ & 37 & M & Fever & Incomplete & No (refused) & No & - & Died 15-d \\
\hline \multirow[t]{2}{*}{$\begin{array}{l}\text { Oizumi et } \\
\text { al. [24] }\end{array}$} & 19 & $\mathrm{~F}$ & $\begin{array}{l}\text { Dyspnea, } \\
\text { fatigue }\end{array}$ & Complete & - & - & Vimentin & Died 7-m \\
\hline & & & & & & & SYT-SSX transcript & \\
\hline $\begin{array}{l}\text { Al-Rajhi et } \\
\text { al. [25] }\end{array}$ & 19 & M & $\begin{array}{l}\text { Shortness of } \\
\text { breath }\end{array}$ & Incomplete & No & Yes & SYT-SSX fusion gene & $\begin{array}{l}\text { No evidence of } \\
\text { disease at } 12 \mathrm{~m}\end{array}$ \\
\hline
\end{tabular}

Due to its extreme rarity, the most effective therapeutic strategy for treating pericardial synovial sarcoma could not be determined, and the complete or near total excision of the tumor was performed in only five of the reported cases [10-13]. The pericardial tumor observed in the present case was also considered to be unresectable, due to its strong attachment to the visceral pericardium [6]. Management of synovial sarcoma of pericardial origin is challenging and needs a multimodal approach. It is an aggressive tumor with a poor prognosis. Most patients have a short survival time. One exception is the case report of a patient whose survival exceeded 14 years and involved recurrences and multiple surgical resections. Surgical resection can lead to curative therapy. Most often, due to the site of origin, tumors are adherent to adjacent vital organs and are non-resectable at the time of diagnosis. Therefore, EBRT and less commonly neo-adjuvant chemotherapy are used to make the tumor resectable [14-18]. In our patient, we could not attempt complete surgical resection. Therefore, after the initial biopsy and pericardial window, neo-adjuvant chemotherapy was done with six cycles of high dose ifosfamide $(2000 \mathrm{mg} / \mathrm{m} 2)$ and mesna. Due to the rarity of these tumors, it is very difficult to establish an optimal regimen for chemotherapy. In general, synovial sarcomas are chemo-sensitive to ifosfamide and show a good response. A case series of 13 patients with synovial sarcoma treated with high-dose ifosfamide showed a response in all patients, with 4 clinical remissions achieved. Combining doxorubicin with ifosfamide may achieve a higher response rate (58\%) but patient tolerability and side effects need to be considered [19-21]. The initial favorable response to neoadjuvant high dose ifosfamide in our patient made the tumor respectable and may be a viable alternative to EBRT alone in non-respectable tumors [5].

EBRT is a very useful modality of treatment post-surgery when the margins of resection are positive. In our patient, EBRT was initiated one month after surgery. Previous reports have shown similar favorable results. To the authors' knowledge only EBRT has been employed in previous cases. Intraoperative Radiation Therapy (IORT) with a radiation dose of 15-45 Gray appeared to be useful for local control and to be more effective in patients without distant metastases at the first visit in a study that included 24 patients with soft tissue sarcomas (1 case of synovial sarcoma) [22-24]. Close monitoring for recurrence is very crucial in management of this tumor. CT or magnetic resonance imaging should be performed every 6 months to detect subclinical recurrences. We performed CT imaging every three months along with regular clinical follow-up or symptoms. Repeat imaging is essential to be able to diagnose subclinical recurrence and initiate repeat broad surgical resection and follow-up chemotherapy if needed. We used the anti-mitotic agent phosphamide for treating the recurrence [5].

Cardiac transplant had been an alternative in some cases with more survival, but it is controversial due to tumoral etiology.

This report described one case of pericardial synovial sarcoma, an extremely rare primary cardiac tumor, despite proper treatment, has an unclear prognosis [25] (Table 1).

\section{References}

1. Lam KY, Dickens P, Chan AC (1993) Tumors of the heart. A 20-year experience with a review of 12,485 consecutive autopsies. Arch Pathol Lab Med 117(10): 1027-1031.

2. Bezerra SG, Brandão AA, Albuquerque DC, Militão RC, Hadlich MS, et al. (2013) Pericardial Synovial Sarcoma: Case Report and Literature Review. Arq Bras Cardiol 101(6): e103-e106.

3. Yoshino M, Sekine Y, Koh E, Kume Y, Saito H, et al. (2013) Pericardial synovial sarcoma. A case report and review of literature. 44(11):21672173.

4. Huo Z, Lu H, Mao Q Jin Z, Wu H, et al. (2015) Primary synovial sarcoma 
of the right heart involving the tricuspid valve in an elderly Chinese woman: a case report. Diagn Pathol 10: 80.

5. Phatak P, Khanagavi J, Aronow WS, Puri S, Yusuf Y, et al. (2014) Pericardial synovial sarcoma: challenges in diagnosis and management. F1000Res 3: 15.

6. Ohzeki M, Fujita S, Miyazaki H, Morita H, Kanki S, et al. (2014) A Patient with Primary Pericardial Synovial Sarcoma who presented with cardiac tamponade: A Case Report and Review of the Literature. Intern Med 53(6): 595-601.

7. Youn HC, Lee Y, Kim SC (2016) Pericardial synovial sarcoma presenting with large recurrent pericardial effusion. J Thorac Dis 8(6): E412-E416.

8. Muramatsu T, Takeshita S, Tanaka Y, Morooka H, Higure R, et al. (2015) Primary pericardial synovial sarcoma. J Thorac Dis 7(10): E496-E498.

9. Cheng Y, Sheng W, Zhou X, Wang J (2012) Pericardial Synovial Sarcoma, a Potencial for Misdiagnosis. Clinicopathologic and Molecular Cytogenetic Analysis of Three Cases with Literature Review. Am J Clin Pathol 137(1): 142-149.

10. Zhang PJ, Brooks JS, Goldblum JR, Yoder B, Seethala R, et al. (2008) Primary cardiac sarcomas: a clinicopathologic analysis of a series with follow-up information in 17 patients and emphasis on long-term survival. Human pathology 39(9): 1385-1395.

11. Cheng Y, Sheng W, Zhou X, Wang J (2012) Pericardial synovial sarcoma, a potential for misdiagnosis: clinicopathologic and molecular cytogenetic analysis of three cases with literature review. Am J Clin Pathol 137(1): 142-149.

12. Akerström F, Santos B, Alguacil AM, Orradre JL, Lima PS, et al. (2011) Pericardial synovial sarcoma. Thorac Cardiovasc Surg 59(3): 175-177.

13. Moorjani N, Peebles C, Gallagher P, Tsang G, et al. (2009) Pericardial synovial sarcoma. J Card Surg 24(3): 349-351.

14. Katakura H, Fukuse T, Shiraishi I, Hayatsu E, Nishijo K, et al. (2009) Mediastinal synovial sarcoma. Thorac Cardiovasc Surg 57(3): 183-185.

15. Korula A, Shah A, Philip MA, Kuruvila K, Pradhip J, et al. (2009) Primary

This work is licensed under Creative

Commons Attribution 4.0 License

DOI: 10.19080/JTMP.2018.03.555614 mediastinal synovial sarcoma with transdiaphragmatic extension presenting as a pericardial effusion. Singapore Med J 50(1): e26-e28.

16. Zhang PJ, Brooks JS, Goldblum JR, Yoder B, Seethala R, et al. (2008) Primary cardiac sarco- mas: a clinicopathologic analysis of a series with follow-up infor- mation in 17 patients and emphasis on long-term survival. Hum Pathol 39(9): 1385-1395.

17. De Zwaan C, Bekkers SC, van Garsse LA, Jansen RL, van Suylen RJ (2007) Primary monophasic mediastinal, cardiac and pericardial synovial sarcoma: a young man in distress. Neth Heart J 15(6): 226-228.

18. Hing SN, Marshall L, Al-Saadi R, Hargrave D (2007) Primary pericardial synovial sarcoma confirmed by molecular genetic studies: a case report. J Pediatr Hematol Oncol 29(7): 492-495.

19. Van der Mieren G, Willems S, Sciot R, Dumez H, Van Oosterom A, et al. (2004) Pericardial synovial sarcoma: 14-year survival with multimodality therapy. Ann Thorac Surg 78(3): e41-e42.

20. Yano M, Toyooka S, Tsukuda K, Dote H, Morimoto Y, et al. (2004) SYTSSX fusion genes in synovial sarcoma of the thorax. Lung Cancer 44(3): 391-397.

21. Anand AK, Khanna A, Sinha SK, Mukherjee U, Walia JS, et al. (2003) Pericardial synovial sarcoma. Clin Oncol (R Coll Radiol) 15: 186-188.

22. Val-Bernal JF, Figols J, Gomez-Roman JJ (2002) Incidental localized (solitary) epithelial mesothelioma of the pericardium: case report and literature review. Cardiovasc Pathol 11(3): 181-185.

23. Dos Santos NR, de Bruijn DR, van Kessel AG (2001) Molecular mechanisms underlying human synovial sarcoma development. Genes Chromosomes Cancer 30(1): 1-14.

24. Oizumi S, Igarashi K, Takenaka T, Yamashiro K, Hiraga H, et al. (1999) Primary pericardial synovial sarcoma with detection of the chimeric transcript SYT- SSX. Jpn Circ J 63(4): 330-332.

25. Al-Rajhi N, Husain S, Coupland R, McNamee C, Jha N (1999) Primary pericardial synovial sarcoma: a case report and literature review. J Surg Oncol 70(3): 194-198.

\section{Your next submission with Juniper Publishers will reach you the below assets}

- Quality Editorial service

- Swift Peer Review

- Reprints availability

- E-prints Service

- Manuscript Podcast for convenient understanding

- Global attainment for your research

- Manuscript accessibility in different formats

( Pdf, E-pub, Full Text, Audio)

- Unceasing customer service

Track the below URL for one-step submission

https://juniperpublishers.com/online-submission.php 